\title{
An Appraisal of the Causes of Delayed Response to Crime Incidents in "Area B" Police Command of Metropolitan Lagos, Nigeria
} Nwoye Casmier Friday*

Department of Management Technology, College of Management Sciences, Bells University of Technology, Ota, Ogun State, Nigeria

\begin{abstract}
Crime incidents in Lagos State, particularly in Metropolitan areas, have become worrisome and have resulted in severe loss of lives and property over the years. Unfortunately the Nigerian Police, which is the major constituted security agency, has not lived up to expectations in terms of responding promptly to crime incidents when they occur in the area. This situation calls for urgent attention, especially now that Lagos State is at an inception stage of being one of the Mega Cities in Africa and in the Globe. Thus, this study aimed at exploring the causes of delayed response to crime in Area B Police Command of Lagos Metropolis. Its focus was to analyze the physical and human variables responsible for delayed responses of the men of Nigerian Police. Physical factors such as accessibility and spatial distribution of Police Divisions within the study area were examined. Human induced factors, as they bolder on attitude and motivations of the respondents were also analyzed. The Methodology involved a combination of quantitative, qualitative and location analysis. Primary spatial and non-spatial data were collected on the field by direct readings as well as field observation, interviews and questionnaire administration to both residents and the police. All these were analysed using GIS and Statistical Packages for Social Sciences (SPSS). The findings revealed that delayed response to crime incidences in the study area resulted from both human and infrastructural factors. Only three of the Police stations were highly accessible while most others were averagely accessible. However, there was a police division with little or no accessibility. This perhaps accounts for the delayed responses to crime incidents occurring in this division. Analysis of questionnaire revealed that most of the residents did not promptly report crime incidences and when they did, the responses was not speedily conveyed because they had reported the incidence through rather slow means. On the part of the police, inadequate welfare and infrastructural facilities accounted for low motivation which invariably fuels delayed response.
\end{abstract}

Keywords: Crime; Quick responses; Policing; Public safety; Accessibility; Motivation

\section{Introduction}

On a global scene, the level of development attained by any nation, or states in a nation is measured on a scale of a number of factors which includes Economy, Technology, and Security etc. Thus, undoubtedly, it can be said that the level of development in any community depends to a large extent on its state of security. In the same vein, every five years, $60 \%$ of city inhabitants have been victims of one form of crime or the other and over half of these crimes have involved property loss Agbola [1]. Violent crimes such as murder, infanticide, assault, rape, sexual abuse, acts of terrorism, buying and selling of women and children etc. constitute another 25 to $30 \%$ of urban crime. These and other forms of urban violence have been perpetrated in European and Latin American communities. The drug trade and anti-social behavior (hooliganism) have singly, as well as collectively, increased in the cities, creating a pervasive feeling of insecurity.

The city is a conductive setting for these types of urban violence and crime, because it provides an anonymity required for individual crime and the space for a specialized and organized underworld. Theft and hooliganism thus become a means of survival if there are no options left, especially in cities which have undergone substantial growth that has resulted in an unbalanced demographic structure, as it borders on wealth distribution.

There is no doubt that, since the mid-seventies, Nigeria has been experiencing what is referred to in criminological literature as a "crime problem" i.e. when crime, in terms of incidence and seriousness, passed from the normal tolerable level to the abnormal and becomes a social problem".

It is therefore pertinent to shed light on the significance of crime detection and control, in societal development. Crime detection is an area of vital importance in Police Department. A crime can be defined as an art (or omission) which is prohibited by the state, and therefore, attracts punishment. Criminal activities continue to be a major concern in contemporary society [2]. In many of the world's industrialized countries, crime rates recorded by the police are many times more than those recorded 30 years ago. United Nations findings showed that for the 1989 - 1996 periods, more than half of the urban respondents reported being victimized at least once regardless of what part of the world they inhabited.

Essentially, the central objective of policing is to provide security or at least social and psychological feeling of security, for a majority of citizens, in a majority of places.

Therefore, as Lagos strives to become one of the mega-cities in the world, there is need to appraise the functionality of the police force - as it relates to timely crime detection and control, towards attaining the globally acceptable security level needed in rating the city as mega and developed in terms of security.

*Corresponding author: Nwoye Casmier Friday, Department of Management Technology, College of Management Sciences, Bells University of Technology, Ota, Ogun State, Nigeria, Tel: 2348094243940; E-mail: webbercas@yahoo.com

Received November 11, 2016; Accepted November 18, 2016; Published November 21, 2016

Citation: Friday NC (2016) An Appraisal of the Causes of Delayed Response to Crime Incidents in "Area B" Police Command of Metropolitan Lagos, Nigeria. Int J Econ Manag Sci 6: 387. doi: 10.4172/2162-6359.1000387

Copyright: ( 2016 Friday NC. This is an open-access article distributed under the terms of the Creative Commons Attribution License, which permits unrestricted use, distribution, and reproduction in any medium, provided the original author and source are credited. 


\section{Statement of Problem}

Violence and crime are a huge threat to public safety. They cause great personal suffering, vast material damage, and place an enormous burden on the urban social network. Yet, as Vanderschueren [3] observed, urban violence has increased worldwide at a rate which has largely surpassed that of urbanization. In the recent past and as it stands now in Lagos and other parts of Nigeria, crime activities are rampant. This is traceable to a number of factors one of which is high unemployment rate. Striking among these insecurity issues are those relating to kidnapping, theft and armed robbery. The cost and consequences of the crime problem for the population are a reality. For the population, the cost and consequences are manifold; in addition to material loss and/or personal distress caused by actual criminal virtualization, there is the debilitating reality of a population's unquantifiable but costly expenditure of energy and scarce resources on anxious fear of and precautionary care against political criminal virtualization - fear and care that must arise out of feelings of insecurity and helplessness and out of a situation they must have assessed as probably hopeless. Criminal activity continues to be a major concern to contemporary societies. As such, most societies move against criminal activities through their instituted security arms such as The Nigerian Police Force in the case of Nigeria and Lagos-as one of the federating states in Nigeria. The Nigerian Police Force is an important security agency saddled with the responsibility of maintaining peace, law and order in the country and Lagos State in particular. Unfortunately however, those saddled with the responsibilities of protecting the community, fall short of what is expected of them. Most times, when these security agencies are called upon to avert an ongoing criminal activity, they either fail to respond or have a delayed response thereby leading to loss of lives, properties and ultimately leaving the inhabitants of the society vulnerable to all kinds of security assaults.

This research therefore focuses on the examination of the causes of delayed responses to crime incidences by the Nigerian police force in metropolitan Lagos. The study focused on the causes of delayed responses to crime in area B police command of metropolitan Lagos.

\section{Aim and Objectives}

The aim of this study is to examine the cause(s) of delayed responses to crime in area B police command of Lagos metropolis.

The specific objectives to achieving this aim are:

i. To examine the pattern of distribution of police divisions in the study area.

ii. To determine the accessibility indices of the police divisions in the study area.

iii. To examine delay on the side of residents.

iv. To assess the motivation of the Nigerian police men alongside their perception and reaction to crime incidences, as well as evaluate and facilities available for quick and timely responses to crime within the study area.

\section{Significance of Study}

No doubt, that a safe and secured society is a catalyst to all developmental processes. Like all other research works therefore, this one has a human face. There is an implication for security policy formulations on the side of the government as it affects proper location and adequate provision of equipment's necessary to maintain law and other in the society. Consequently, there will result a huge decrease in the loss of lives, properties and other valuable resources on the side of the inhabitants of the society as criminal activities will almost be checked instantaneously each time they occur. To the outside world generally, there will be a safe security assurance necessary to attract local and foreign investors into Lagos for commercial and other economic activities thereby creating gainful employment opportunities. This will, as a social chain reaction, further reduce crime in the study area and within Lagos state generally.

\section{Scope of Study}

The study is limited only to the examination of the cause(s) of delayed responses to crime incidences when they occur in the study area. The study is therefore approached from two angles of view. The first perspective examines delay as a function of physical factors such as those relating to the location of the police divisions within the study area and the indices of accessibility of the stations.

However, the other perspective to the study examines delay as relating to cultural factors. Some of the cultural factors examined include the means of communicating crime incidences to the constituted security authorities on the side of the residents. Nonetheless, other human factor issues such as those relating to the availability of the necessary equipment's for timely responses to crime incidences and those relating to motivation and attitude on the side of the constituted authority were all, also examined. The study area was picked because it is one of the areas of relatively high incidences of crime activities (armed robbery) requiring timely responses-as revealed by the data collected from Lagos State Police Command, Ikeja.

\section{Study Area}

The study area for this project work comprises Area B Command of the Nigerian Police Force which covers three local government areas within metropolitan Lagos. The local government areas are: Apapa, Ajeromi Ifelodun and Amuwo Odofin. However, it is important to state that only one of the nine police divisions in the study area fall in Amuwo Odofin (Figure 1).

\section{Limitations to the Study}

Quite a number of limitations were encountered during the entire process of the research. These constraints slowed down the pace at which the study was conducted. The major problem arose in the collection of crime data from the Police Force. Their records were not up to date and were disjointed as they were not collated. Other major problems arose during the distribution and collection of questionnaires. The respondents (both the police men and others) were not cooperative in filling their questionnaires. It required a lot of persuasion on the side of the members of the public before they could be inveigled to fill the questionnaires. However, interview methods were adopted to acquire the necessary information from members of the Nigerian Police Force within the study area when they failed to cooperate.

\section{Methodology}

The data for the study were acquired from two sources: primary and secondary. The secondary data were derived from library research. Books, journals and reports on the subject matter of crime, the concept of accessibility as well as those of motivation and attitude were all gotten. Also, the internet was browsed for relevant information. Information regarding crime records and other issues relating to police station within the area of study were collected from the Lagos 
Citation: Friday NC (2016) An Appraisal of the Causes of Delayed Response to Crime Incidents in "Area B" Police Command of Metropolitan Lagos, Nigeria. Int J Econ Manag Sci 6: 387. doi: 10.4172/2162-6359.1000387

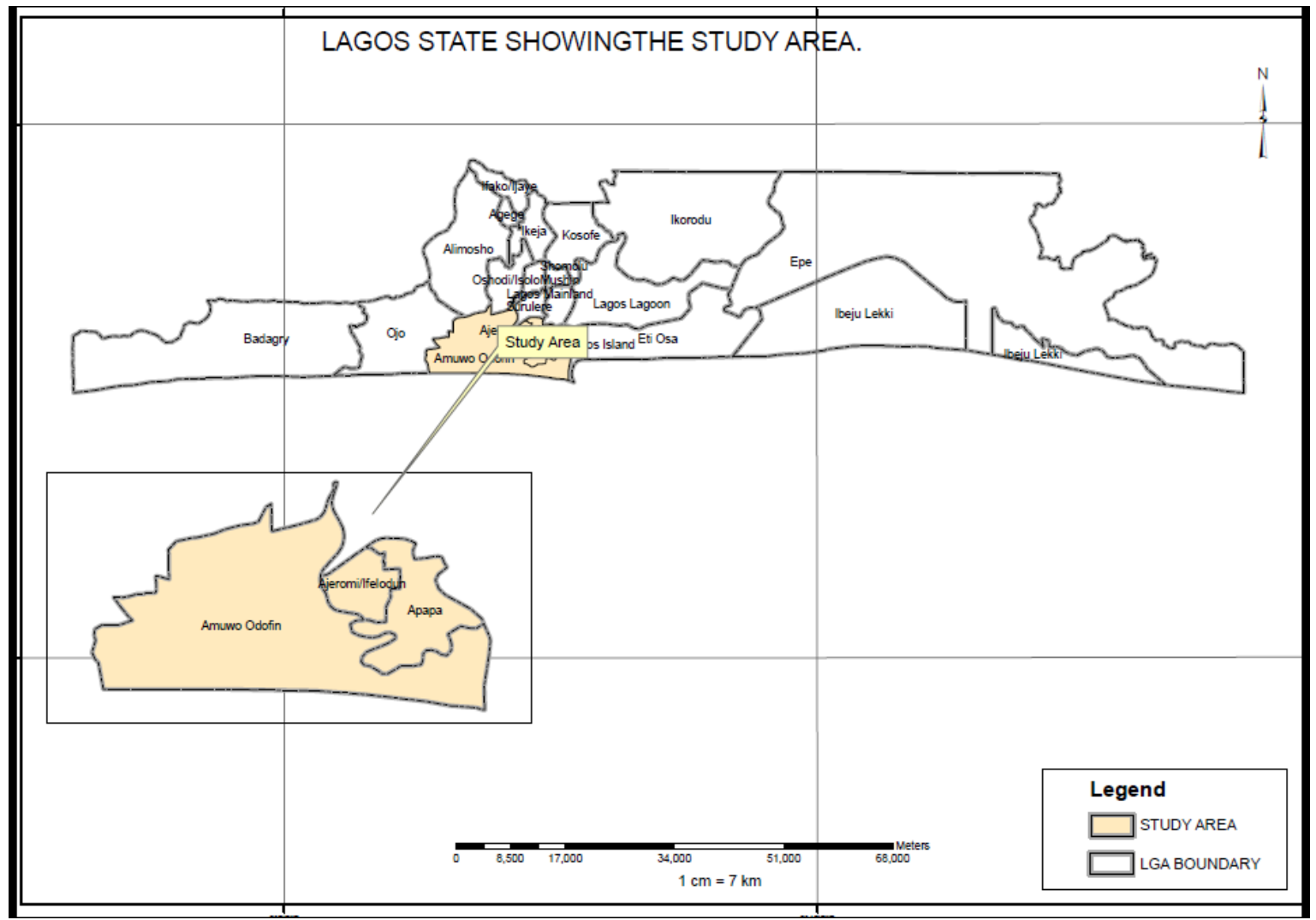

Figure 1: Study area

State Police Command, Ikeja and the Police Public Relations office at Oduduwa crescent, GRA, Ikeja

The primary aspatial data were obtained through questionnaires drawn up for the study. There were two questionnaires involved; one for the residents of the study area and another for the police officers accordingly. Copies of both questionnaires are in the appendix. Copies of questionnaires were distributed to respondents (residents and officers) in Apapa Local Government Area, Amuwo Odofin Local Government Area and Ajeromi Ifelodun Local Government Area which make up area B of the Lagos state Police command. Two hundred questionnaires were prepared for the residents in the Three Local Government Areas. Forty questionnaires were administered to officers in the Police divisions within the study area. Eighty questionnaires were administered to respondents at Apapa and Ajeromi Ifelodun Local Government Areas, while the remaining forty questionnaires were administered at Amuwo Odofin Local Government Area.

\section{Spatial data acquisition}

The spatial data was obtained directly from the field and police formations. The plot attributes such as address, name etc. were obtained directly from the site. A hand-held Global positioning systems (GPS-76) was taken to the field to obtain the 8 component points represented in Table 1 below. The facility gave the longitude and latitude (i.e. Easting's and Northings) of these points which were recorded concurrently and entered into the table package of the ARC MAP.

This segment discussed methods used in converting analogue data to digital formats.

\begin{tabular}{|c|c|c|c|c|}
\hline S/N & Name of Station & Address & \multicolumn{2}{|c|}{ Graticles } \\
\cline { 4 - 5 } & & & Northing & Easthing \\
\hline B0 & COMMAND HQ APAPA & Barracks bus-stop Apapa & 6.44960 & 3.36743 \\
\hline B1 & Apapa Division & Barracks bus-stop Apapa & 6.45012 & 3.36753 \\
\hline B2 & Ajegunle Division & Opp. Ajeromi LGA & 6.45531 & 3.34404 \\
\hline B3 & Trinity Division & Trinity Bus-stop Ajegunle & 6.46020 & 3.32725 \\
\hline B4 & Layeni Division & Layeni st, Ajegunle & 6.46651 & 3.34752 \\
\hline B5 & Amukoko Division & Amukoko & 6.44031 & 3.34497 \\
\hline B6 & Tolu Division & Temidire/Tolu St, Ajegunle & 6.44243 & 3.32539 \\
\hline B7 & Kirikiri Division & Kirikiri & 6.44331 & 3.31185 \\
\hline B8 & Badia ljora division & Ojora Olaye ljora 7up & 6.46832 & 3.35682 \\
\hline
\end{tabular}

Source: Field survey, 2016.

Table 1: Police Divisions in Area B Command.

The analogue map of the study area was converted into digital format through the on-screen digitalization exercise within the arcview GIS environment, where the coordinate of the police divisions obtained using GPS, which was saved in Microsoft Excel as a Data base IV file was added as an event theme.

Some of the data base of the attribute data acquired were created using Microsoft Excel and saved into Dbase IV file and imported into Arc view GIS 9.3 as an event theme while some were directly created in Arc view GIS 9.3.

The data analysis was done within Arc-view GIS (9.3) software environment, using measuring tools to get the nearest neighborhood analysis for the distribution of police divisions in the study area. The road network map of the study area, with an intensive field work for 
Citation: Friday NC (2016) An Appraisal of the Causes of Delayed Response to Crime Incidents in "Area B" Police Command of Metropolitan Lagos, Nigeria. Int J Econ Manag Sci 6: 387. doi: 10.4172/2162-6359.1000387

the assessment of roads, was used to calculate the accessibility index for each police station within the study area. Catchment area analysis was also done by buffer concepts. Statistical packages such as SPSS and EXCEL were used to analyze the questionnaires. The data and results were presented in tabular, graphical and text format. Also, maps were used to represent the results. In addition, statistical methods were used to find averages and percentages.

\section{Results and Discussions}

This chapter presents the data collected and analyzed. These include the location of the various police divisions within the study area, the information captured by the research questionnaire, the nearest neighbor analysis result and the accessibility indices of the police divisions.

\section{The distribution of police divisions in the study area}

Table 1 below shows the coordinate distribution of the different police divisions in the study area as were recorded on the field. There was one command headquarters and eight police divisions in all. Area B Command has a total of 8 police Divisions. The Divisions are distributed among 3 local government areas which are AjeromiIfelodun, Apapa and Amuwo Odofin LGAs. Under Ajeromi Ifelodun LGA, we have Ajegunle, Trinity, Layeni, Amukoko and Tolu Divisions while Apapa LGA, where the Area B Command Headqurter is located has Apapa, and Badia Ijora Divisions only Kiriki Division falls in Amuwo Odofin LGA.

\section{Nearest neighborhood analysis}

Most spatial phenomena often appear on maps as dots. Dot distributions are commonly used in Geography, yet their pattern are difficult to describe. One way in which a pattern can be measured objectively is by using nearest neighbor analysis. For this project, the nearest neighborhood analysis was done within a typical GIS environment. The GPS readings for the police divisions were imported into the ARC GIS environment. The ARC catalogue tool box was used to calculate the nearest NNI for the police divisions within the study area. The result for the $\mathrm{Rn}$ value was 1.83 which indicates that the pattern of distribution for the police divisions is dispersed. It however signifies that the distribution tends towards regularity. The implication of this is that there are little or no areas left unserved. Delayed responses to crime incidences will result, if the police divisions are not spatially evenly distributed and certain areas are left unserved while others are served by more than one police divisions. A map (Figure 2) of the study area is shown below with the distribution of the police divisions.

\section{Accessibility indices of the police divisions}

The components of accessibility calculation include the type, class (quality), and number of roads leading to the different police divisions within the study area. Therefore, adopting the approach of Ajaegbu and Faniran [4], Dogo [5] by assigning scores to accessibility variables for each police station, the following scoring scheme could be arrived at.

For Types of roads

Trunk A=4;

Trunk B=3;

Trunk $\mathrm{C}=2$,

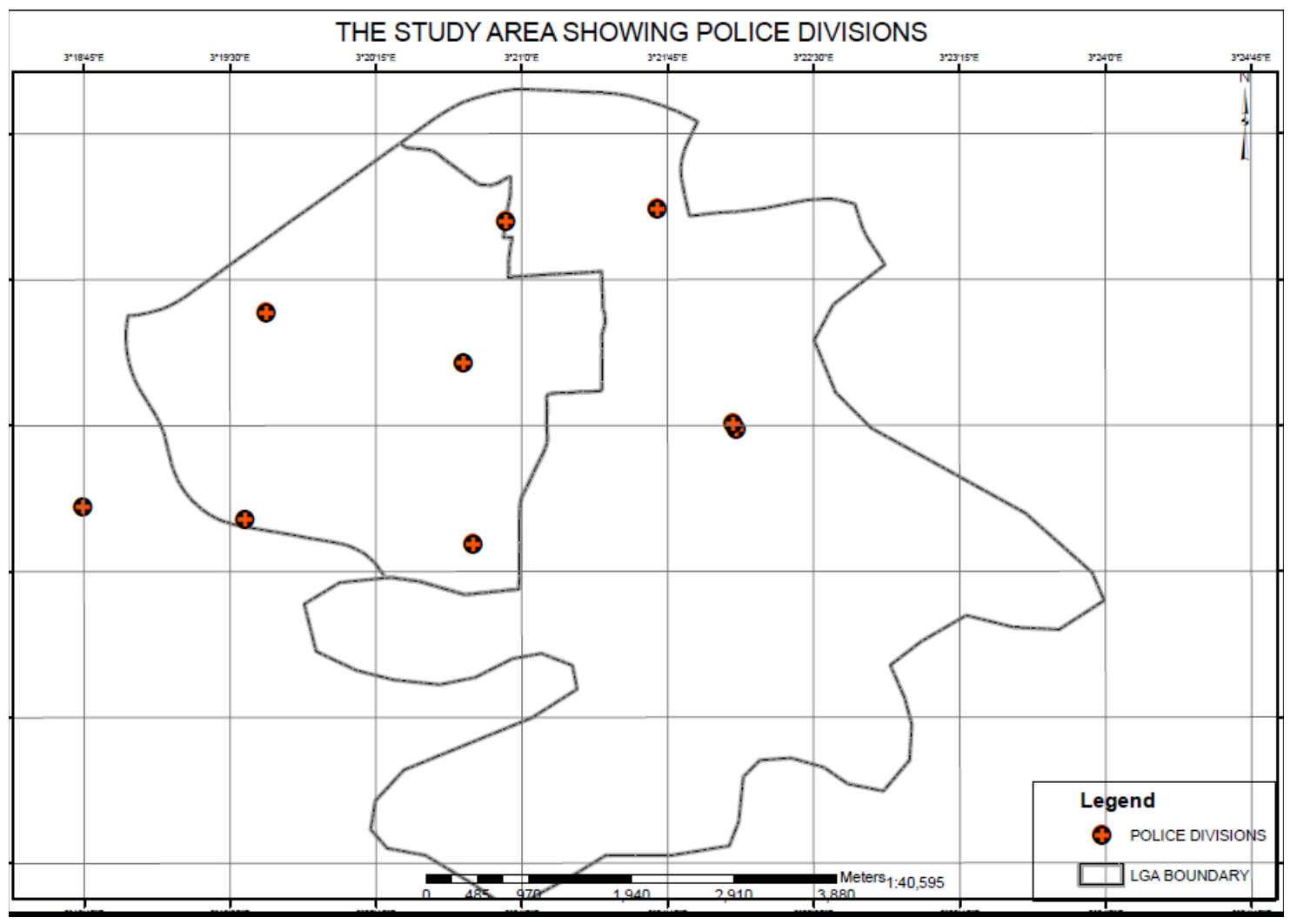

Figure 2: Spatial Distribution of police divisions in Area B Police Command. 
Citation: Friday NC (2016) An Appraisal of the Causes of Delayed Response to Crime Incidents in "Area B" Police Command of Metropolitan Lagos, Nigeria. Int J Econ Manag Sci 6: 387. doi: 10.4172/2162-6359.1000387

Page 5 of 10

For quality of roads

Tarred all seasoned roads $=4$;

Untarred all season roads $=3$;

Ditch ridden roads $=2$,

Number of road links

Each link=1

The situation of the police divisions, with respect to the accessibility variables mentioned above, is given below. The implication of accessibility to delayed responses is not farfetched. This is because areas of high accessibility are easily accessed and can access other areas within the same transportation network and beyond. The road network map (Figure 3) of the study area, with the police divisions is shown below (Tables 2, 3 and Figure 4).

From the information above, only three police divisions are relatively highly accessible. These are; Command HQ; Apapa Division; and Kirikiri Division. Tolu Division is relatively poor in accessibility, while others can be rated as average.

\section{Questionnaire Analysis-Residents}

This section presents the analysis of the questionnaire administered to the residents of the three local government areas making-up the study area.

\section{Sex distribution of respondents}

Of the total number of respondents which was 197, 45.2\% were male while the remaining $54.8 \%$ were female (Table 4 ).

\section{Age distribution of respondents}

In all, 27 people were less than 20 years of age. 66 of the respondents were between the ages of 21 and 30.78 others were between the ages of 31 and 40. The number of those falling within the age group of between 41 and 51 was 20 . Only 2 people were older than 50 years. The remaining 4 people did not provide their ages (Figure 5).

\section{Lenght of stay in study area by respondents}

This information is necesarry as it goes to validate the statements and conclussions drawn on the incidences and prevalence of crime in the study are. A total of 105 people which represents about $66.5 \%$ of the 158 people who provided the lenght of their stay, had stayed in the area for more than 6 years. 33.5\% of those who provided their lenght of stay had stayed in the area for between 0 and 5 years. Only 39 people did not provide their lenght of stay in the study area (Table 5).

\section{Crime experiences by respondents}

A total of 193 respondents reacted to the question of whether or not they had experienced crime incidences in the study area. One hunderd and forty nine people (149) which represents $77.2 \%$ had experienced crime at different time periods. Only 44 people which represents $22.8 \%$ of the 193 people who responded to this question had never experienced any form of crime. The remaining 4 people were indifferent [6] (Figure 6).

\section{The type of predominant crime in the study area}

The questionnaire revealed that the most predominant crime was armed robbery with a total of 63 respondents, which amounts to $41.4 \%$ of the total of 152 people who responded to this question. Trailing

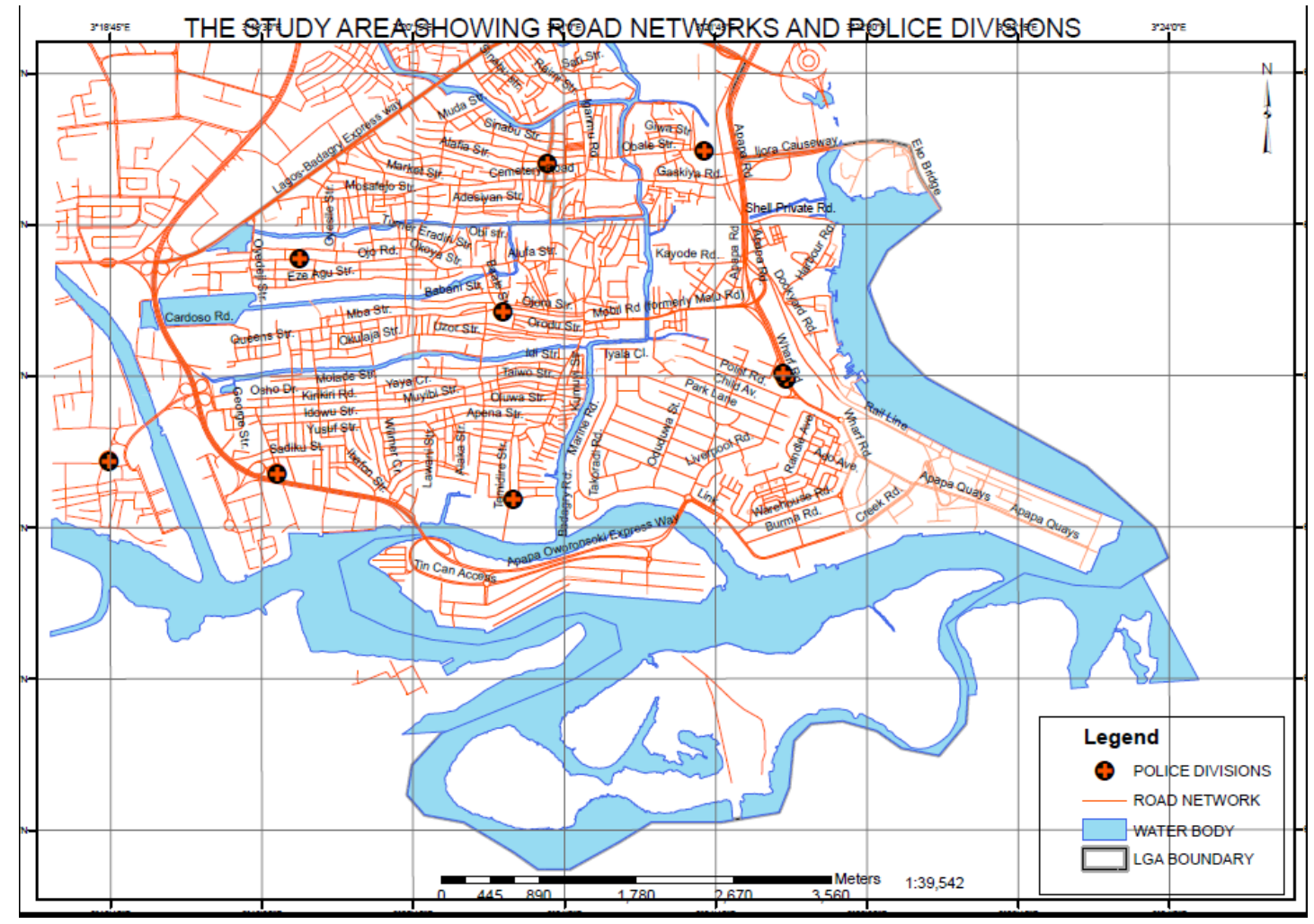

Figure 3: Road Connectivity of Police Divisions in Area B police Command. 
Citation: Friday NC (2016) An Appraisal of the Causes of Delayed Response to Crime Incidents in "Area B" Police Command of Metropolitan Lagos, Nigeria. Int J Econ Manag Sci 6: 387. doi: 10.4172/2162-6359.1000387

\begin{tabular}{|l|c|c|c|c|c|c|c|c|}
\hline S/N & Name of station & $\begin{array}{c}\text { No of } \\
\text { roads }\end{array}$ & \multicolumn{2}{|c|}{$\begin{array}{c}\text { Class of } \\
\text { roads }\end{array}$} & \multicolumn{3}{|c|}{ Quality of roads } \\
\cline { 3 - 7 } & & & A & B & C & Tarred & Untarred & $\begin{array}{c}\text { Dicth- } \\
\text { ridden }\end{array}$ \\
\hline B0 & $\begin{array}{c}\text { COMMAND HQ } \\
\text { APAPA }\end{array}$ & 3 & & 2 & 1 & 3 & & \\
\hline B1 & Apapa Division & 3 & 2 & 1 & 3 & & \\
\hline B2 & Ajegunle Division & 3 & 2 & 1 & & & 3 \\
\hline B3 & Trinity Division & 2 & 2 & & 2 & & \\
\hline B4 & Layeni Division & 2 & & 2 & & 2 & & \\
\hline B5 & Amukoko Division & 2 & & 2 & & 2 & & \\
\hline B6 & Tolu Division & 2 & & & 2 & & 2 & \\
\hline B7 & Kirikiri Division & 3 & & 2 & 1 & 3 & & \\
\hline B8 & Badia ljora division & 2 & & 2 & & 2 & & \\
\hline
\end{tabular}

Source: Field survey, 2016.

Table 2: Variables for indices of accessibility calculation.

\begin{tabular}{|c|c|c|c|c|}
\hline \multirow{2}{*}{ Name of station } & \multicolumn{3}{|c|}{ Accessibility scores } & \multirow{2}{*}{ Total score (index) } \\
\cline { 2 - 4 } & Road type & Road quality & Links & \\
\hline COMMAND HQ APAPA & 8 & 12 & 3 & 23 \\
\hline Apapa Division & 8 & 12 & 3 & 23 \\
\hline Ajegunle Division & 8 & 6 & 3 & 17 \\
\hline Trinity Division & 6 & 8 & 2 & 16 \\
\hline Layeni Division & 6 & 8 & 2 & 16 \\
\hline Amukoko Division & 6 & 8 & 2 & 16 \\
\hline Tolu Division & 4 & 6 & 2 & 12 \\
\hline Kirikiri Division & 8 & 12 & 3 & 23 \\
\hline Badia ljora division & 6 & 8 & 2 & 16 \\
\hline
\end{tabular}

Source: Field survey, 2016.

Table 3: Accessibility Indices of Police Stations in Area B Police Command.

\section{ACCESSIBILITY INDICES}

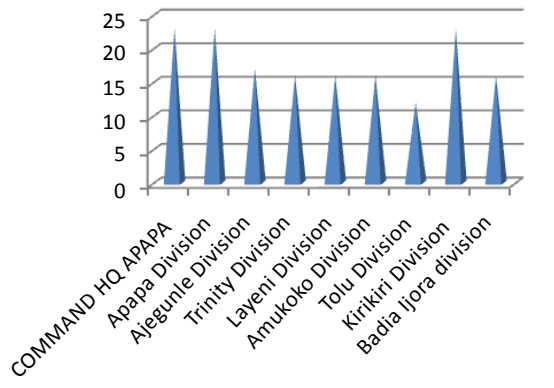

ACCESSIBILITY INDICES

Figure 4: Accessibility Indices chat for the Police divisions.

\begin{tabular}{|c|c|c|}
\hline & & Percentage \\
\hline Male & 89 & 45.2 \\
\hline Female & 108 & 54.8 \\
\hline Total & 197 & 100 \\
\hline
\end{tabular}

Source: Field survey, 2016

Table 4: Sex Distribution of Respondents.

behind this is Burglary which had 42 respondents (27.6\%). Theft has a total of 39 respondents which amounts to $25.7 \%$. Other kinds of crime make up about $5.3 \%$ by having a total of 8 respondents (Figure 7).

\section{Recency of crime incidences in the study area}

This tried to capture the time of the most recent crime incidences in the study area. A total of 149 people responded to this question. 29

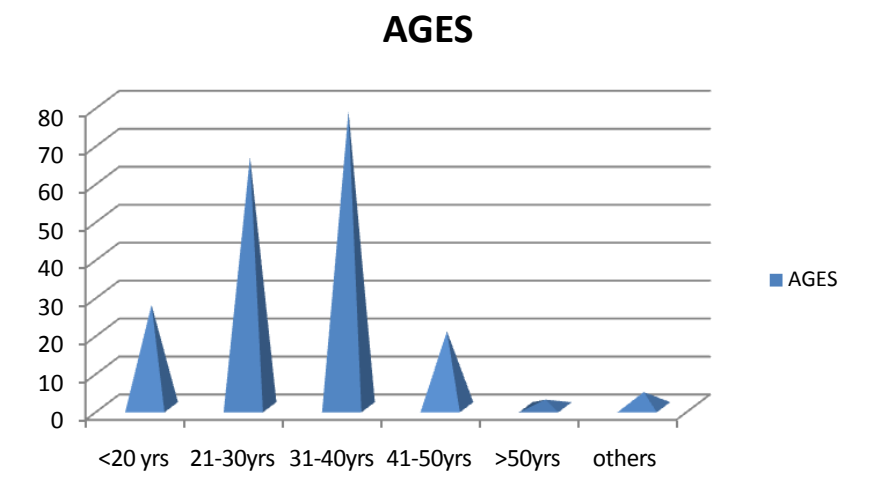

Figure 5: Age Distribution of Respondents.

\begin{tabular}{|c|c|c|}
\hline & & Percentage \\
\hline$<5$ yrs & 53 & 33.5 \\
\hline $6-10 y r s$ & 65 & 41.1 \\
\hline $11-20 y r s$ & 23 & 14.6 \\
\hline$>20 y r s$ & 17 & 10.8 \\
\hline Total & 158 & 100.0 \\
\hline
\end{tabular}

Source: Field survey, 2016.

Table 5: Lenght of stay of respondents in study area.

\section{CRIME EXPERIENCE}

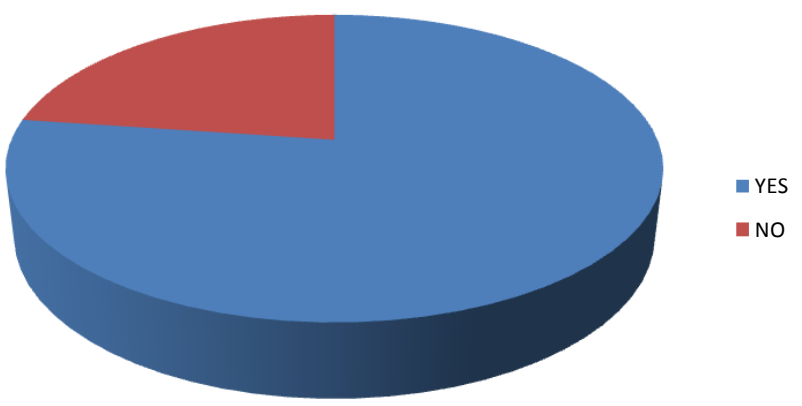

Figure 6: Crime Experience by Residents in Study area

PREDOMINANCE OF CRIME

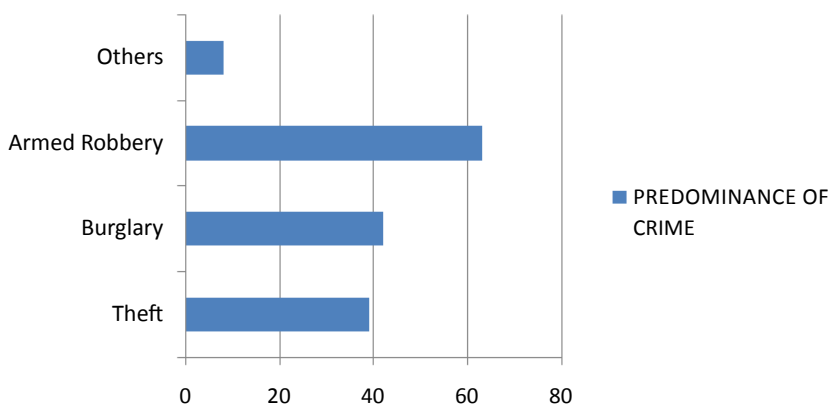

Figure 7: Predominant crime types in study area.

people which represents $19.5 \%$ of them had experienced crime in less than a year ago. Thirty six (36) peeople which represents about $24.2 \%$ had experienced crime between the last one and two years. Eighty four people which represents $56.4 \%$ had however experienced crime over 
Citation: Friday NC (2016) An Appraisal of the Causes of Delayed Response to Crime Incidents in "Area B" Police Command of Metropolitan Lagos, Nigeria. Int J Econ Manag Sci 6: 387. doi: 10.4172/2162-6359.1000387

two years ago. This implies that crime incidence has dropped in the last two years within the study area $[7,8]$ (Table 6).

\section{Reports of crime incidence to security agents}

This question was to capture whether or not residents in the study area actually do contact any security agent or any constituted security authority as may be within thier reach at incidences of crimes that require timely response. In all, 151 people responded to this question. Of these, 110 people, which represents $72.8 \%$ responded in the affirmative, while 41 people which represents $27.2 \%$ did not contact any security agent.

\section{Security agents contacted in cases of crime}

With respect to this question, a total of 111 people responded. Of these, one hundred and ten respondents, which represents $99.1 \%$ said they contacted the Nigeria Police at incidences where they experienced crime. Only one (1) person however admitted to have called other security agents and this represents $0.9 \%$ (Table 7 ).

\section{Delays in contacting security agents}

This tried to capture delayed responses to crime cases, as a function of the lapse rate of time on the side of the residents before the case is reported to the security authorities $[9,10]$. The results showed that 82 people which represents $73.9 \%$ reported their crime cases promptly. Another ten people, which amouts to about 9\% reported after ten minutes. 6 people said they reported thiers after about between 11-30 minutes. This represents $5.4 \%$. Only 13 people reported after thirty minutes and this represents $11.7 \%$. The implication of this, is that the timeliness of the security agents' reponse, to crime incidences, is directly dependent on how promtly crime reports get to them (Table 8a).

\section{Means of contacting security agents}

The motive here, was to further establish delays inherent in the means of contacting the security agents on the side of the respondents. Only 31 people used the fastest means of communication-telephone and this represents $27.2 \%$ of the total of the 114 respondents who

\begin{tabular}{|c|c|c|}
\hline \multicolumn{2}{|c|}{ Regency of crime } & Percentage \\
\hline$<1$ yr ago & 29 & 19.5 \\
\hline $1-2$ yrs ago & 36 & 24.2 \\
\hline$>2$ yrs ago & 84 & 56.4 \\
\hline Total & 149 & 100 \\
\hline
\end{tabular}

Source: Field survey, 2016.

Table 6: Recency of crime in study area.

\begin{tabular}{|c|c|c|}
\hline \multicolumn{2}{|c|}{ Security agents contacted at crime incidences } & Percentage \\
\hline Nigeria Police & 110 & 99.1 \\
\hline Others & 1 & 0.9 \\
\hline Total & 111 & 100.0 \\
\hline
\end{tabular}

Source: Field survey, 2016.

Table 7: Security Agents Contacted At Crime Incidences.

\begin{tabular}{|c|c|c|}
\hline \multicolumn{2}{|c|}{ Delays in contacting security agents } & Percentages \\
\hline Promptly & 82 & 73.9 \\
\hline After 10 min & 10 & 9.0 \\
\hline $11-30$ min & 6 & 5.4 \\
\hline After30 min & 13 & 11.7 \\
\hline Total & 111 & 100.0 \\
\hline
\end{tabular}

Source: Field survey, 2016.

Table 8a: Residents delays in contacting security agents. attended to this question. 32 people, which represents $28.1 \%$ used public transport means to contact the security agents. Finally, majority of the respondents which stands at 51 people, contacted the agents via personal or direct means (Table $8 \mathrm{~b}$ ).

\section{Security agents' response}

This question was designed to capture whether or not the security agents, having recieved distress calls from residents, responded to such calls. A total of one hundred and nine people responded. Ninety one of these, which represents $83.5 \%$ of the people said yes, that the security agents responded, while the remaining eighteen people which represents $16.5 \%$ said no (Table 9).

\section{Timeliness of security agents' response}

This section attempts to analyse delays traceable to the response of the security agents and this represents $53.3 \%$. Another 17 people claimed that the security agents did not come at all-this represents $15.9 \%$. Finally 33 people said the security agents came on time-which represents $30.8 \%$. An evaluation of the delay, as provided by the respondents, on the side of the officers, revealed an alarming statistics. 94 people responded to this question. Of these, 32 respondents stated that the security agents had a delay period of between 1-3 hours, 14 people said that the officers had a delay period of between $30-60$ minutes. Only 13 people stated that the officers had a delay period of more than three hours before arriving at the scene of the crime, after receiving distress calls or alerts. This shows a clear indication of the problem of delayed responses to crime incidences in the study area (Table 10).

\section{Assessment of security agents' response}

The idea in this section is to attempt to find out the satisfaction of the residents on the operation of the contacted security agents. A total of 110 people responded. More than half of the respondents seemed to be pleased with the operation of the security agents. 34 people which-represents $30.9 \%$, rated their response as effective. 19 people which-represent $17.3 \%$, rated their response as average. 57 people which- represents $51.8 \%$, rated thier response as not-effective (Figure 8).

\begin{tabular}{|c|c|c|}
\hline \multicolumn{2}{|c|}{ Means of contacting security agents } & Percentages \\
\hline Phone calls & 31 & 27.2 \\
\hline Public means & 32 & 28.1 \\
\hline Private means & 51 & 44.7 \\
\hline Total & 114 & 100.0 \\
\hline
\end{tabular}

Source: Field survey, 2016.

Table 8b: Means of contacting security agents

\begin{tabular}{|c|c|c|}
\hline \multicolumn{2}{|c|}{ Security agents' response } & Percentages \\
\hline Yes & 91 & 83.5 \\
\hline No & 18 & 16.5 \\
\hline Total & 109 & 100.0 \\
\hline
\end{tabular}

Table 9: Security agents response to distress calls.

\begin{tabular}{|c|c|c|}
\hline \multicolumn{2}{|c|}{ Timeliness of security agent's response } & Percentages \\
\hline Delayed & 57 & 53.3 \\
\hline Never Came & 17 & 15.9 \\
\hline On Time & 33 & 30.8 \\
\hline Total & 107 & 100 \\
\hline
\end{tabular}

Source: Field survey, 2016.

Table 10: Time liness of officers' response to crime incidences. 
ASSESSMENT OF SECURITY AGENTS' RESPONSE

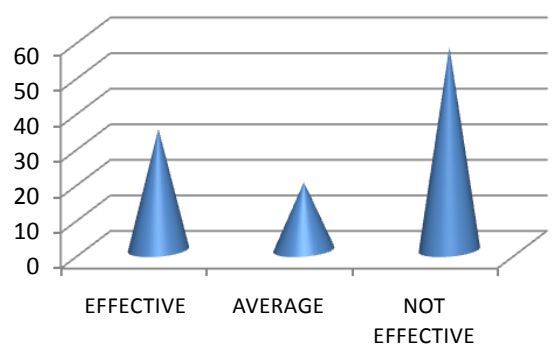

ASSESSMENT OF SECURITY AGENTS' RESPONSE

Figure 8: Assessment of officers' response.

\begin{tabular}{|c|c|c|}
\hline $\begin{array}{c}\text { Ranks of responding } \\
\text { officers }\end{array}$ & Frequency & Percentage \\
\hline Sergent & 4 & 16.0 \\
\hline Inspector & 3 & 12.0 \\
\hline Corporal & 5 & 20.0 \\
\hline Constable & 6 & 24.0 \\
\hline Superintendent & 1 & 4.0 \\
\hline Assistant Superintendent & 3 & 12.0 \\
\hline Chief Superintendent & 2 & 8.0 \\
\hline Deputy Superintendent & 1 & 4.0 \\
\hline Total & 25 & 100.0 \\
\hline
\end{tabular}

Source: Field survey, 2016.

Table 11: Ranks of responding officers.

\section{Perspectives on residents' apathy in contacting security agents}

A total of 35 people did not contact any security agents at incendences of crime. However they gave reasons for not contacting security agents .12 people, which represents $34.3 \%$, said they did not contact them because, over time, the security agents have not been effective and do not usually respond. 6 people, which represents $17.1 \%$, said they did not contact them because they did not know the numbers to call. 5 people, which represents $14.3 \%$, said they were scared of the unknown and were devastated. Finally, 4 people, which represent $11.4 \%$, said the crime did not affect them. Other categories were 8 , which represents $22.9 \%$.

\section{Analysis of questionnaire-police officers}

This section presents the analysis of the questionnaires administered to the officers of the police divisions in the three local government areas making-up the study area. The Divisions are distributed among 3 local government areas which are Ajeromi-Ifelodun, Apapa and Amuwo Odofin LGAs. Under Ajeromi Ifelodun LGA, we have Ajegunle, Trinity, Layeni, Amukoko and Tolu Divisions while Apapa LGA, where the Area B Command Headqurter is located has Apapa, and Badia Ijora Divisions only Kiriki Division falls in Amuwo Odofin LGA.

However, officers from Amukoko and Apapa police divisions could not be accessed because of the absence of their bosses.

\section{Sex and age distribution of officers}

A total of twenty five police officers returned the questionnaires administered to them. Of these, twenty officers, which represents $80 \%$ was male while the remainder, which represents $20 \%$, was female, the number of officers, who were between the ages of thirty and fifty years were 13. Eight officers were less than thirty years of age while only four officers were older than fifty years of age.

\section{Rank distribution and education of officers}

The ranks of all the officers who responded to the research questionnaire, with their corresponding frequencies are provided below in Table 11.

$56 \%$ of the officers have secondary education while thirty six percent of the remainder have tertiary education. Those who claim to have other kinds of education account for $8 \%$ which represents two officers only.

\section{Possession of publicly known telephone lines by police divisions}

The question was to investigate whether or not there are general telephone lines, for each of the police divisions within the study area, that the public can assess during incidences of crime. The result however showed that none of the police divisions has a private telephone line. They only depend on the central distress call phone lines, from where crime incidences in their areas of jurisdiction are forwarded to them.

\section{Receiving crime reports by police divisions}

The officers stated that they receive crime reports through such means as reports in person and through telephone calls. This is to further investigate what the residents stated and uncover delays in the means by which reports of crime are given to the officers. Fifteen officers which represents $57.7 \%$ claimed to receive crime reports by personal notifications. Ten other officers said they receive the reports via telephone lines.

\section{Possession of patrol vans and thier maintenance}

It was discovered that all the police divisions within the study area possess between 2 to 5 patrol vans. Most of the patrol vans were provided by the federal and state governments respectively. A few of the vans were provided by NGOs and the host communities. Over $92 \%$ of the vans are beteween zero to five years old. In terms of maintenance however, the response from officers showed that they are the ones who are responsible for the maintenance of the patrol vans. The communities and the government contribute little or no efforts to this.

\section{Temporal distribution of officers' duty shifts and drivers}

This question was designed to investigate the temporal structure of the duty shifts, as well as the number of drivers per shift, of the officers of the Nigerian Police Force. This was to evaluate delays as a result of inadequacy or unavailability of drivers to drive patrol vans at incidences of crime. The result showed that the officers run three cyclically continous duty shifts. These are morning, afternoon and night duties. With respect to the number of drivers per shift, there was variation. $8.3 \%$ of the officers said that they don't have any driver in their shift, $58.4 \%$ of these officers said that they have between 2-5 drivers per shift, while the remaining $33.3 \%$ said they have only one driver per shift. There is an implication for delay in these statistics. There is a high probability of the occurrence of delay for those duty shifts with no drivers at all at cases of crime incidence. Delayed response to crime incidences will result on the side of those officers with only one driver per shift, where there more than one crime incidences occurring concurently.

\section{Assessment of officers' welfare and motivation}

This question was designed to capture the care and attention 
given to officers as to motivate them to quickly discharge their duties, with respect to distress calls. Majority of the officers rated the the performance of the government as poor, in this regard. Sixteen officers, which represents $64 \%$ accounts for this. Those who rated the performance of the government as average were 8 and this accounts for $32 \%$. It was also stated that the efforts of government, in taking care of the family members of any officer who dies on the job, is disheartening. A total of 16 officers, which represents $64 \%$ stated that the government does not take care of the family members of the deceased officers at all. Only 9 officers anwered in the affirmative to this question. In terms of reward for any outstanding officer(s) who foils crime or apprehends criminals, most of the officers stated that they are not given any. Sixteen officers, which represents $61.5 \%$ said there are no such rewards known to them. However, 10 officers, which represents $38.5 \%$ had their response as yes. The few officers who admitted, stated that the rewards come in form of promotion and monetary terms.

\section{Possession of surveillance cameras by police divisions}

According to the responses received from the officers, there were no surveillance cameras in all the police divisions in the study area.

\section{Conclusion}

The general crime rate in the study area is on the decrease. The causes of delayed responses to crime are mainly due to the inefficiency on the side of the government to provide the necessary care for members of the Nigeria Police as well as improve on the provision and maintenance of equipment's needed to respond on time to crime incidences. They have also failed to complement the centralized telephone system and notify the public of the exact numbers to call within specified geographical locations for timely responses to crime. The failure on the part of government to put roads in proper motorable conditions, as to increase the speed of accessibility, during crime incidences, is also part of the causes of delayed responses to crime. On the side of the officers, they have failed to structure the distribution of drivers, such that, at least two drivers will be available per duty shift to respond to the needs of residents when they arise. This is also a serious cause of delay to crime incidences. On the side of residents, delays were caused because as a result of time lapse in the means used to contact the security agents.

\section{Suggestion and Recommendation}

Following the research findings, these suggestions and recommendations were made.

\section{The following suggestions are directed to the government.}

Given the fact that most criminal activities-such as those relating to robbery, theft and burglary are, often times than not, premised on the altar of merciless struggles for survival, schools should be made to add public counseling sessions into their curriculum to develop students and to orientate students on how to become good citizens of the country, against all odds. Also, there is the need for government to look into the falling standards of education because this is what makes most graduates unemployable as to make them resort to all kinds of social vices as a means of livelihood. For the employable but unemployed people, government should provide job opportunities for them and the thousands of youths graduating from the tertiary institutions every year. They should also encourage youth to take soft loans and start small-scale businesses either on their own or in coalition with others.

With respect to the unpleasing state of the welfare of the officers, government should revisit the policies formulated in this regard. Government should have an encouraging plan on the ground for officers of the Nigeria Police, such that, they will be willing to take all risks, knowing that all will be well with their family members, in the case of death, or having the assurance that they will be given the best care and medications, in the case of severe or minor injury.

In terms of the equipment for fighting crime and responding on time to distress calls resulting from crime incidences, government should provide and maintain all necessary equipment needed to maintain law and order in the state. Also, government should complement the centralized emergency telephone system in use. Each police division should have some publicly known telephone lines for communities within their areas of influence. Finally, government should ensure that roads leading to police divisions are tarred and devoid of pot holes to aid free flow of traffic when they need to respond on time to distress calls.

As it borders on psychological motivation, government should ensure that rewards are given to outstanding officers when they foil criminal activities or apprehend criminals. This will serve as motivation and enhance the performance of the officers. Surveillance cameras should also be provided at strategic locations to aid effective operations of the police force. The use of Helicopters should also be encouraged to aid timely responses to criminal activities within the study area and the state at large.

The following suggestions are directed to the people.

There is need for families to remain in love. This is because records have shown that most criminals are the outcome of failed marriages and heterogeneous settings. Families should bring up their children by teaching them the norms of the society. They should also put the fear of God in them and teach them some facts of life, "honesty is the best policy", "there is dignity in labour".

People should become more security conscious about their environment. They should report suspected movements and people to the police immediately. People should also realize that they need to report all cases of crime to the police. The people should endeavor to have the telephone numbers of the police divisions in their area at all times and not only when there is crime. This will aid a timely reporting of crime incidences and therefore aid a timely response on the side of the police.

For further studies and research, an attempt should be made to discover the way areas of influence of police divisions in Lagos state are delineated. This is to access areas not served by any police station and therefore becomes prone to delayed responses. Also, a research into the functionality and usefulness of real-time surveillance cameras, as may be married with Geographic Information System, to aid geo-tracking, should be carried out.

\section{References}

1. Agbola T (1997) The architecture of fear. A pilot study of planning, urban design and construction reaction to urban violence in Africa.

2. Fajemirokun FO, Adewale, Ayinla N (2006) A GIS approach to crime mapping and management in Nigeria: a case study of victoria island lagos pp: 1-17.

3. Vanderschueren F (1996) Urban Violence, Justice and Poverty. Habitat Debate 2-3

4. Ajaegbu HO, Faniran A (1973) A new approach to practical geography. Ibadan, Nigeria, Heinemabb, educational books.

5. Dogo B (1998) A depiction and analysis of the levels of rural road provision 
Citation: Friday NC (2016) An Appraisal of the Causes of Delayed Response to Crime Incidents in "Area B" Police Command of Metropolitan Lagos, Nigeria. Int J Econ Manag Sci 6: 387. doi: 10.4172/2162-6359.1000387

Page 10 of 10

in the Jos plateau. A Paper presented at the $41^{\text {st }}$ annual conference of the Nigerian geographical association held at university of Oyo.

6. Domenach J (1978) The ubiquity of violence. International social science journal 30: 717-726.

7. Lagos Metropolitan Transport Authority Annual Report, (LAMATA, 2003).
8. Nigerian population commission, report of population and housing census (NPC 2006)

9. United Nations (1998) Annual Report, USA.

10. Webber M (1947) The theory of social and economic organization (translated by AM Henderson and Talcott Persons) NY: The Free Press, USA. 